\title{
The Effectiveness of Various Types of Feedback on Primary Stage Students' Writing
}

Engy Mahmoud Ahmed

An English Language Teacher

Prof. Dr. Aly A. Qoura , Dr. Samah Rezk Hassan

Prof. of Curriculum\&Instruction(TEFL)Faculty of Education

Mansoura University

\section{Abstract:}

his study aimed at investigating the effectiveness of
using various types of feedback on students' writings
at the primary school to enhance their ability to express their ideas. This study adopted the quasi experimental design. The participants of the study were forty students in the sixth year primary school. They were divided randomly into three experimental groups. The first one received oral conferences feedback while the second one got peer feedback. The third group was provided the traditional written feedback directly by teachers. Instruments of the study were a pre-post EFL writing test and a writing rubric to assess pupils' writing according to the identified sub-skills. The instruction using various types of feedback was applied in the first term of academic year (2016/2017) and lasted for two months. The findings suggested that using Oral Conferences Feedback affects students' writing in a positive way than providing only the traditional written feedback from teachers or Peer Feedback. Oral Conferences Feedback enhances students motivation to practise writing skill. It provides opportunities for pupils to negotiate the meaning and clarify teachers' written Feedback.

Key Words: Writing Skill- Oral Conferences Feedback- Peer Feedback- Teacher Written Feedback

\section{Introduction}

Admitting the importance of writing in ESL classrooms, teachers are interested in assigning various strategies that can help pupils to improve and scaffold their writing skill. However, because of obstacles, such as, time constraint and large number of pupils to attend to, teachers may find it difficult to provide feedback on pupils' written work. The process of writing in a foreign language is special, because it is a complex cognitive 
application that requires drafting, revising, and editing. Writing should not only be included in the school curricula as a skill but also as a critical element. Pupils of process writing need appropriate and timely feedback on their work, and moreover, training in dealing with that feedback whether it is oral feedback in conferences teachers' feedback or peer feedback. Peer review encourages pupils to participate in the writing process in a deeper, more fruitful and meaningful way.

\section{Review of Literature:}

In traditional teaching, most of the emphasis tends to be on the pupils doing reading and writing skills, probably because it seems to keep them quiet and it is easier to organize the classroom. Similarly, most teachers probably do most of the talking. While the students do most of the listening, with a questionable amount of understanding. Writing is different to speaking as there is no immediate feedback. Writing has more permanence. Moreover, writing gives more time and chance to plan.

\section{Writing:}

Writing has been considered an essential skill in English language acquisition. Such importance is due to the clear fact that it enhances grammatical structures and vocabulary that teachers strive to teach their pupils. Acquisition English is the field in which learners need to be offered suitable time to develop their writing skill, that's why more time, should be devoted to this skill in classrooms containing English language learners.

\section{Writing Sub-Skills:}

There are many sub-skills of writing; copying that gives pupil model examples to promote success rather than failure, filling in the blanks that encourages limited creativity on a correct base, parallel writing that encourages creative/guided writing with reference to model examples, describing a picture or series of pictures that further encourages creative/guided writing, but with a given situation/stories line to guarantee words flowing, completion of a sentence/paragraph which gives more practice in writing from clues, editing and drafting that 
gives practice in finding and correcting mistakes (either to be your own mistakes or others) in grammar, spelling and content and finally reacting to a situation which encourages written responses to everyday situations.

\section{Importance of Writing:}

Writing is an important skill in many professions and fields of study. It is a powerful tool for communication, self-expression, and learning Graham (2006). In school settings, effective writing can lead to improvements in reading comprehension Hebert, Gillespie, \& Graham (2013) and overall academic achievement. However, writing is not an easy skill to master. The process of writing can be challenging for even experienced writers. Writing fosters our ability to explain and presents our ideas to others and ourselves.

\section{Feedback:}

Feedback is defined by Hattie and Timperley (2007) as information provided by an educator according to aspects of one's achievement or perception. The aim of feedback is to reduce the gap between current understanding and the target correction Hattie and Timperley (2007). Feedback is a manifold topic within L2 writing development and it is something teachers spend much time on. Some teachers waste much time giving feedback in details thinking that in this way student's writing may improve, Leki (1990). Polio (2012) declares that feedback needs to be on the suitable level for the pupils.

\section{Importance of Feedback:}

It is necessary to get the fact that there are many types of feedback. Two types have received great concern, direct and indirect corrective feedback. While indirect strategies indicate to conditions that the teacher refers as an error has been made but does not supply a correction leaving the pupils to identify and correct it, direct or explicit feedback happens when the teacher determine an error and provides the right form. It can include defining a word that is not necessary in the context, the insertion of a missing article, or the provision of the suitable linguistic 
form around or near the linguistic mistake Bitchener (2005). Oral and written feedback, are two significant types of feedback have been under the spotlight in recent EFL research. Ellis (2004) illustrated written and oral feedback as being distinctive. The former is delayed whereas the latter occurs at once after an error has been made. Learners rely on their short-term memory. Both feedback types are believed to be effective in L2 Learning, but the current study seeks to find which one is more effective comparing to other types of peer feedback.

\section{Types of Feedback:}

\section{Oral Conference Feedback:}

Oral feedback is one of the techniques applied by teachers to promote interaction and resolve confusions and contradictions. Therefore, oral feedback provided during face-toface interaction has many positive effects/benefits for students' writing and for their learning experiences in general. Individual conferences develop dialogical skills in students as they interact with their teachers who engage in debates with their students, generate ideas, help them focus on their research, guide them to conform with writing requirements as well as to plan and act appropriately to complete their work (Wisker, et al., 2003). At the same time, oral feedback provides opportunities for students to seek clarification for their teachers' written feedback on their writing (Zamel, 1985). In face-to-face meetings with their teachers, students are able to negotiate meaning as they seek clarification and generally expect positive outcomes (Goldstein \& Conrad, 1990; Wang \& Li, 2011).

\section{Peer Feedback:}

Peer feedback is a method of mutual interaction that may be considered as a solution that can be worked effectively rather than the various types of feedback given in a large class. The studies proved that first; peer feedback is pitched more at the learner's level of progress or interest. It is therefore more informative than teacher feedback. Secondly, it enhances pupils' awareness and enables them to see the mistakes in their own 
writing. In addition, pupils' attitudes towards writing can be supported with the help of more encouraging peers and their anxiety can be lowered. Pupils can be aware more about writing by checking each other's drafts critically. Their awareness of what makes writing better is connected to the amounts of times of writing. Pupils eventually become more autonomous writers. Peer feedback has its limitations. For instance, there are three major problems of peer feedback: pupils tend to respond to surface errors instead of semantic or textual one; pupils give advice that often does not facilitate revision; and pupils have difficulty deciding whether their peer's feedback is valid.

\section{Teacher Written Feedback:}

While teacher feedback has been specified to be desirable for the progress of pupils' writing (Ferris \& Roberts, 2001; Ferris, 2004; Goldstein, 2004; Zhang, 1995) argument continues over whether written feedback should be provided as it is often neglected and misunderstood by pupils (Bitchener, Young \& Cameron, 2005; Guénette, 2007; Truscott, 1996). Pupils avoid teacher feedback for being product-oriented because it occurs most frequently at the end point due to time and class size constraints (Yang, Badger \& Yu, 2006). It has also been argued that while higher-achieving pupils seem to respond in a positive way and benefit from teacher feedback, lower-achieving pupils respond poorly and constantly need to be encouraged to comprehend the teacher's comments (Guénette, 2007). When students did not receive any feedback they had no opportunity to practice the structure. But when they received feedback on their errors in each session they had enough opportunity to practice the structure, so they improved their skill in article system of English.

\section{The Effectiveness of Feedback on Students' Motivation:}

The positive effects of writing can be greatly reduced by flawed implementation like any pedagogical tool. The main factor that influences the effect of writing activities is the nature of the feedback pupils receive. Pupils may receive no feedback at all or may be only get a grade with no comments about their specific 
performance. As a result, pupils get some writing practice but generally don't improve and don't learn the material better. Writing loses its potency when it becomes a onetime event instead of an ongoing process. Abiddin and West (2007) point out that pupils can become more familiar with their written work as well as improving their writing sub-skills if they can do more talking to explain their work to their teachers. Pupils should be writing multiple drafts and improving their work each time with the help of a writing guide.

A Chinese study by Miao et al. (2006) investigated the differences between peer feedback and teacher feedback. They followed two groups of students for a period of time, and there were 79 pupils altogether. The findings were that the students acted more upon the teacher feedback than the peer feedback. Pupils found teacher feedback more trustworthy than peer feedback, so they used the teacher feedback more. However, when the peer feedback was acted upon, the revisions were more successful than the teacher feedback revisions.

A total of 119 preparatory pupils were involved in a study by Wei-chen Chuang (2009). They received different kinds of feedback for the grammatical mistakes in their writing. The study showed that the group with the student-teacher conferences and the group combining the peer-to-peer interaction with studentteacher conferencing outperformed the group receiving only written correction from the teacher and the group receiving no feedback in their post-treatment writings.

Nooreiny Maarof, Hamidah Yamat and Kee Li Li (2011) examined ESL pupils' perception of the role of teacher, peer and combined teacher-peer feedback in ESL writing. Results from the study showed that most of the pupils welcome the combined use of teacher and peer feedback in ESL writing. An implication of this study is that the two forms of feedback can play an important and complementary role in enhancing the acquisition of writing among ESL pupils.

Kea Leaph (2011) investigated the perceptions about effectiveness of oral and written feedback on writing of thirty- 
seven Cambodian English-major students. Results show that both the groups equally delivered better performance on holistic writing although oral feedback was viewed as preferable to written feedback.

\section{Statement of the problem:}

Based on the review of literature, related studies, 6th grade primary pupils face a variety of needs, from basic skills reinforcement as self-editing and proofreading to coaching in essay writing through which pupils need to practise and master sub-skills of writing before going on to apply the suitable type of feedback. Thus, the current study investigates the effect of frequent oral conferences feedback, peer feedback, or direct written teacher feedback for enhancing EFL primary school pupils' writing skills and their motivation towards writing.

\section{Pilot Study}

Results of the pilot study (table 1) showed that primary school pupils need help to enhance their writing skills. To provide evidence for the problem of the study, the researcher conducted a pilot study on $6^{\text {th }}$ grade primary pupils randomly selected from Mansoura College Language School in Mansoura city. The test administrated in duration of 20 minutes. An English writing test was designed by the researcher and validated by three EFL senior teachers and two supervisors.

Table (1) Pupils' Scores in the Placement Test

\begin{tabular}{|c|c|c|c|c|c|}
\hline School & Number & $\begin{array}{c}\text { Maximum } \\
\text { score of the } \\
\text { English test }\end{array}$ & $\begin{array}{c}\text { Writing } \\
\text { maximum } \\
\text { score }\end{array}$ & $\begin{array}{c}\text { Mean } \\
\text { Score }\end{array}$ & Percentage \\
\hline $\begin{array}{c}\text { Mansoura } \\
\text { College } \\
\text { Schools }\end{array}$ & 30 & 40 & 14 & 6.5 & $\% 56.7$ \\
\hline
\end{tabular}

This table shows that pupils' total mean score in writing skill was 6.5 and their total percentage was 56.7 which in turn indicated that the pupils' level in English writing in general and sentence construction in particular needs improvement. The highest mean score was 1.7 in the organization sub-skill while the lowest mean was 1.2 in the conventions sub-skill. This level 
may be due to a number of variables that include the lack of training in using appropriate writing learning strategies.

\section{Questions:}

1. What are the types of feedback required for enhancing the $6^{\text {th }}$ grade primary pupils' writing skills?

2. What is the effectiveness of using specific types of feedback (Oral Conferences feedback, Peer feedback, and Direct Teacher Written feedback in enhancing EFL writing skills for $6^{\text {th }}$ grade primary stage pupils?

3. How can the frequent variety of feedback affect the motivation of $6^{\text {th }}$ grade primary stage pupils' writing?

\section{Purposes:}

1. Promoting $6^{\text {th }}$ primary students' English writing skills through different types of feedback.

2. Familiarizing students with how to effectively use various types of feedback in order to make gains in their writing performance.

3. Investigating the impact of using these various types of feedback $6^{\text {th }}$ primary pupils' motivation to write.

\section{Design:}

The study adopted the quasi-experimental design using three experimental groups to prove the effectiveness of using a variety of feedback methods on scaffolding $6^{\text {th }}$ grade students' writing. The first experimental group received Oral Conferences Feedback, while the second group received Peer Feedback. The last group received Direct Teacher Written Feedback. All groups received the pre and post - administration of the writing test.

\section{Instruments:}

1. A rubric for determining the sub-skills necessary for developing $6^{\text {th }}$ primary pupils writing.

2. Pre - post EFL writing test to evaluate $6^{\text {th }}$ primary pupils' accuracy in writing performance.

3. A motivation scale for assessing $6^{\text {th }}$ primary pupils' improvements in writing performance. 


\section{Hypotheses:}

\section{The First Hypothesis:}

The first hypothesis states that there is a statistically significant difference at the .05 level between the mean score of the experimental group in the pre- post EFL test in the Oral Conferences Feedback in favor of post administration. There are differences between means of both the pre-test and the post-test in dimensions of correct spelling, suitable vocab, organized way, punctuation, tenses, meaning and the total score in group 1 "Oral Conferences Feedback".

Table (2) Comparing The Performance of the Oral Conference Feedback Group on The Pre-Post EFL Writing Test

\begin{tabular}{|c|c|c|c|c|}
\hline & Writing Sub-skills & Mean & N & Std. Deviation \\
\hline \multirow{2}{*}{ Pair 1 } & Correct Spelling 1 & 1.42 & 13 & .534 \\
& Correct Spelling 2 & 1.96 & 13 & .320 \\
\hline \multirow{2}{*}{ Pair 2 } & Suitable vocab 1 & 1.07 & 13 & .640 \\
& Suitable vocab 2 & $\mathbf{1 . 8 4}$ & 13 & .240 \\
\hline \multirow{2}{*}{ Pair 3 } & Organized Way 1 & 1.50 & 13 & .500 \\
& Organized Way 2 & 1.88 & 13 & .299 \\
\hline \multirow{2}{*}{ Pair 4 } & Punctuation 1 & 1.84 & 13 & .473 \\
& Punctuation 2 & $\mathbf{2 . 3 0}$ & 13 & .383 \\
\hline \multirow{2}{*}{ Pair 5 } & Tenses 1 & 1.11 & 13 & .416 \\
& Tenses 2 & $\mathbf{1 . 8 4 6 2}$ & 13 & .240 \\
\hline \multirow{2}{*}{ Pair 6 } & Meaning 1 & 2.07 & 13 & .493 \\
& Meaning 2 & 2.76 & 13 & .330 \\
\hline \multirow{2}{*}{ Pair 7 } & Total pre-test & $\mathbf{9 . 0 3}$ & 13 & $\mathbf{2 . 1 8}$ \\
& Total post-test & 12.6 & 13 & .506 \\
\hline
\end{tabular}

Table (2) represents the performance of the Oral Conferences Feedback group on the pre and post administration of the EFL writing test using the paired sample t-test. The prepost writing test shows that there is statistical significance between the mean score of the pupils in both the pre-post writing test administrations in favor of the post writing test with a mean score (12.6).

\section{The Second Hypothesis}

It states that there is a statistically significant difference at the .05 level between the mean score of the experimental group in the pre- post EFL test in the Peer Feedback in favor of post administration. There are differences between means of both the 
pre-test and the post-test in dimensions of correct spelling, suitable vocab, organized way, punctuation, tenses, meaning and the total score in group 2 "Peer Feedback".

Table (3) Comparing The Performance of the Peer Feedback Group on The Pre-Post EFL Writing Test

\begin{tabular}{|c|c|c|c|c|}
\hline & Writing Sub-skills & Mean & N & Std. Deviation \\
\hline \multirow{2}{*}{ Pair 1 } & Correct Spelling 1 & 1.42 & 13 & .493 \\
& Correct Spelling 2 & 1.73 & 13 & .259 \\
\hline \multirow{2}{*}{ Pair 2 } & Suitable vocab 1 & 1.07 & 13 & .449 \\
& Suitable vocab 2 & 1.73 & 13 & .388 \\
\hline \multirow{2}{*}{ Pair 3 } & Organized Way 1 & 1.42 & 13 & .400 \\
& Organized Way 2 & 1.84 & 13 & .315 \\
\hline \multirow{2}{*}{ Pair 4 } & Punctuation 1 & 2.00 & 13 & .500 \\
& Punctuation 2 & 2.26 & 13 & .388 \\
\hline \multirow{2}{*}{ Pair 5 } & Tenses 1 & 1.15 & 13 & .427 \\
\hline \multirow{2}{*}{ Pair 6 } & Tenses 2 & 1.84 & 13 & .315 \\
\hline \multirow{2}{*}{ Pair 7 } & Meaning 1 & 2.23 & 13 & .438 \\
& Meaning 2 & 2.50 & 13 & .456 \\
\hline
\end{tabular}

Table (3) represents the performance of the Peer Feedback group on the pre and post administration of the EFL writing test using the paired sample t-test. The pre-post writing test shows that there is statistical significance between the mean score of the pupils in both the pre-post writing test administrations in favor of the post writing test with a mean score (11.9).

\section{The Third Hypothesis}

It states that there is a statistically significant difference at the .05 level between the mean score of the experimental group in the pre- post EFL test in the Direct Teacher Written Feedback in favor of post administration. There are differences between means of both the pre-test and the post-test in dimensions of correct spelling, suitable vocab, organized way, punctuation, tenses, meaning and the total score in group 3 "Direct written Feedback from Teachers".

Table (4) represents the performance of the Direct Teacher Written Feedback group on the pre and post administration of the EFL writing test using the paired sample t-test. The pre-post writing test shows that there is statistical significance between 
the mean score of the pupils in both the pre-post writing test administrations in favor of the post writing test with a mean score (10.7).

Table (4) Comparing The Performance of the Direct Written

Teacher Feedback Group on The Pre-Post EFL Writing Test

\begin{tabular}{|c|c|c|c|c|}
\hline & Writing Sub-skills & Mean & N & Std. Deviation \\
\hline \multirow{2}{*}{ Pair 1 } & Correct Spelling 1 & 1.42 & 14 & .513 \\
& Correct Spelling 2 & 1.53 & 14 & .365 \\
\hline \multirow{2}{*}{ Pair 2 } & Suitable vocab 1 & 1.10 & 14 & .487 \\
& Suitable vocab 2 & 1.57 & 14 & .432 \\
\hline \multirow{2}{*}{ Pair 3 } & Organized Way 1 & 1.46 & 14 & .307 \\
& Organized Way 2 & 1.39 & 14 & .400 \\
\hline \multirow{2}{*}{ Pair 4 } & Punctuation 1 & 1.89 & 14 & .525 \\
& Punctuation 2 & 1.96 & 14 & .498 \\
\hline \multirow{2}{*}{ Pair 5 } & Tenses 1 & 1.14 & 14 & .497 \\
& Tenses 2 & 1.82 & 14 & .316 \\
\hline \multirow{2}{*}{ Pair 6 } & Meaning 1 & 2.28 & 14 & .425 \\
& Meaning 2 & 2.42 & 14 & .331 \\
\hline \multirow{2}{*}{ Pair 7 } & Total pre-test & 9.32 & 14 & 1.77 \\
& Total post-test & 10.7 & 14 & 1.10 \\
\hline
\end{tabular}

\section{The Fourth Hypothesis:}

It states that there is a statistically significant difference at the .05 level between the mean score of the three experimental groups in the pre- post EFL test in favor of the group of Oral Conferences Feedback. There are differences in the post- test between scores of the three groups "Oral Conferences, Peer Feedback and Direct Teacher Feedback" in the dimensions of correct spelling, suitable vocab, organized way, punctuation, tenses, meaning and the total score.

Table (5) Results of the EFL Writing Post Test for the three Feedback Groups

\begin{tabular}{|c|c|c|c|c|c|}
\hline & $\begin{array}{c}\text { Sum of } \\
\text { Squares }\end{array}$ & Df & $\begin{array}{c}\text { Mean } \\
\text { Square }\end{array}$ & F & Sig. \\
\hline Between Groups & 25.1 & 2 & 12.5 & 16.6 & .000 \\
\hline Within Groups & 27.8 & 37 & .753 & & \\
\hline Total & 52.9 & 39 & & & \\
\hline
\end{tabular}

To validate the results, the mean score of the three groups have been compared using one-way ANOVA. The results have been shown in the previous table to determine the progress of the three groups. There is a statistical significance at the level 
0.01 among the score of the three groups in developing the accuracy of the pupils. The $F$ value $(16.6)$ was statistically significant because the $p$ value $(0.00)$ was $<0.01$ which indicates that the differences among the groups are statistically significant. To specify which of the groups of different types of feedback is the most effective in developing the pupils' performance in writing, the Scheffe test was used in post-hoc comparisons.

Table (6) Comparisons of The Effect of each Type of Feedback on Students' writing Performance

\begin{tabular}{|c|c|c|c|c|}
\hline $\begin{array}{c}\text { Dependent } \\
\text { Variable } \\
\text { (group) } \\
\text { Total }\end{array}$ & $\begin{array}{c}\text { Mean } \\
\text { Difference }\end{array}$ & $\begin{array}{c}\text { Group 1 } \\
\text { Oral } \\
\text { Conference } \\
\text { Feedback }\end{array}$ & $\begin{array}{c}\text { Group 2 } \\
\text { Peer } \\
\text { Feedback }\end{array}$ & $\begin{array}{c}\text { Group 3 } \\
\text { Direct } \\
\text { Written } \\
\text { Feedback }\end{array}$ \\
\hline Group 1 & 12.6 & --- & & \\
\hline Group 2 & 11.9 & & --- & \\
\hline Group 3 & 10.7 & $1.90^{*}$ & $1.20^{*}$ & ---- \\
\hline
\end{tabular}

This table explains that there is statistical difference between the accuracy mean score of the three groups; Oral Conference Feedback, Peer Feedback and Direct Written Feedback from teachers. The difference between the mean scores is in favor of group 10ral Conference Feedback (12.6). This score is statistically significant at the level (0.05) reflecting the supremacy of the Oral Conference Feedback over Peer Feedback group with a mean difference (11.9) and over Direct Written Feedback from teachers with a mean difference (10.7) as measured by the post-test.

\section{The Fifth Hypothesis:}

It states that there is a statistically significant difference at the .05 level between the mean score of the three experimental groups in the pre and post administration of the writing motivation scale in favor of the post one.

The writing motivation scale measured pupils' motivation towards writing after receiving the three types of feedback.

Table (7) Post-Motivation Scale

\begin{tabular}{|c|c|c|c|c|c|}
\hline & $\begin{array}{c}\text { Sum of } \\
\text { Squares }\end{array}$ & Df & $\begin{array}{c}\text { Mean } \\
\text { Square }\end{array}$ & F & Sig. \\
\hline Between Groups & 2304 & 2 & 1152 & 39.6 & .000 \\
\hline Within Groups & 2525 & 87 & 29.03 & & \\
\hline Total & 4830 & 89 & & & \\
\hline
\end{tabular}


To validate the results, the mean score of the three groups have been compared using one-way ANOVA. The results have been shown in the previous table to determine the motivation of the three groups. There is a statistical significance at the level 0.01 among the score of the three groups in developing the motivation among the pupils. The $F$ value (39.6) was statistically significant because the $p$ value $(0.00)$ was $<0.01$ which indicates that the differences among the groups are statistically significant. To specify which of the groups of different types of feedback is the most effective in enhancing the pupils' motivation in writing, the Scheffe test was used in post-hoc comparisons.

\section{Discussion of Results :}

The previous results and discussion led to conclude that EFL sixth primary grade pupils' writing sub-skills have been improved. The experimental treatment, applying specific types of feedback, was effective in improving pupils' writing skill and enhancing their motivation. Oral Conferences feedback is determined to be the most effective type of feedback that pupils prefer to receive rather than Peer Feedback or Direct Written Teacher feedback. Pupils were encouraged to use oral conference feedback in order to improve their performance during the writing activities. The high increase in the motivation level in the first experimental group post-application is due to applying some writing activities using oral conference feedback in which students could discuss and communicate with their teachers freely. In this study, teachers focused on the writing process as a whole through applying oral conference feedback rather than the content only in written feedback by teachers or peer feedback.

\section{Conclusions:}

1. The obtained results showed that the writing skill is a complex activity that requires much time and practice on the learners' part and a lot of experience and guidance on the teachers' part. Each type of feedback contributes to effective writing.

2. While providing written feedback by teachers, students couldn't not understand all of the written comments. The 
results show that most of teachers' written feedback was teacher-centered. It made students passive and dependent on teachers. It is important for teachers to be aware of the impact of their feedback practices on student expectations and attitudes, which should be fed back to teachers to help them develop reflective and effective feedback practices.

3. There is more need to help students fully utilize the feedback given to achieve improvements in their piece of writing. Teachers need to response and judge on pupils' writing as a work in progress rather than as a finished product.

4. A useful strategy of an effective feedback methodology is that of a short teacher-student conference. Having a person-to-person conference might sound ideal but not always possible because of time, number of students or nature of mistakes.

5. The primary findings from the students' writings reported that the students were able to correct most of the errors quite well through collaborative activities.

\section{Recommendations:}

1. The students' English proficiency is different in a class, which can be perceived through various errors students have made in their writings. It's a good channel for a teacher to know his or her students' learning through the errors or mistakes they make.

2. This study suggests that Oral Conferences feedback can be applicable in different learning environments, not only in face-to-face but also in blended-learning and distance learning environments. In large classes it demands teacher's dedication and passion for the success of student learning. When deciding to provide Oral Conferences feedback using technology at a distance, careful planning should be made far in advance.

3. Since previous studies supported by the current one claim that peer editing helps to improve the students' language 
proficiency and promote their writing, such peer editing should be used to correct students' mistakes.

4. Peer editing supports a variety of interaction: peer-peer, student-teacher. Students can publish their thoughts and obtain feedback from the others at any time. They do not have to depend much on the teacher. It is a safe and comfortable learning environment for students to work within.

\section{Suggestions for further research:}

1. Further research is needed to study encoded feedback that points to the exact location of an error, and the type of error involved (e.g. PS means an error in the use or form of the past simple tense).

2. Further research is needed to examine students' attitude towards different types of feedback especially oral conferences feedback.

\section{References}

Abiddin, N. Z., \& West, M. (2007). Effective Meeting in Graduate Research Student Supervision. Journal of Social Sciences, 3 (1), 27-35.

Bitchener, J., Cameron, D., \& Young S. (2005). The effect of different types of corrective feedback on ESL student writing. Journal of Second Language Writing, 14 (3), 191205.

Ellis, N. (2005). At the interface: Dynamic interactions of explicit and implicit language knowledge. Studies in Second Language Acquisition 27: 305-352.

Ferris, D., \& Roberts, B. (2001). Error feedback in L2 writing classes: How explicit does it need to be? Journal of Second Language Writing, 10, 161- 184.

Ferris, D.R. (2004). The "grammar correction" debate in L2 writing: Where are we, and where do we go from here? (and what do we do on the meantime?). Journal of Second Language Writing, 13(1), 49-62.

Graham, S. (2006). Listening comprehension: The learners' perspective. System, 34, 165-182. 
Gillespie, A., Graham, S., \& Hebert, M. (2014). High school teachers' use of writing to support students' learning: A national survey. Reading and Writing, 27(6), 1043-1072.

Goldstein, L., \& Conrad, S. (1990). Student input and negotiation of meaning in ESL conferences. TESOL Quarterly, 24(3), 443-460.

Goldstein, L. M. (2004). Questions and answers about teacher written commentary and student revision: Teachers and students working together. Journal of Second Language Writing, 13, 63-80.

Guénette, D. (2007). Is feedback pedagogically correct? Research design issues in studies of feedback on writing. Journal of Second Language Writing, 16, 40-53.

Hattie, J., \& Timperley, H. (2007). The power of feedback. Review of Educational Research, 77(1), 81-112.

Ismail, E. (2013). The Effect of the Genre-Based Approach to Teaching Writing on the EFL Al-Azhar Secondary Students' Writing Skills and their attitudes towards writing, Mansoura University. (pp 50-53)

Ismail, S. (2011). Exploring students' perceptions of ESL writing. English Language Teaching, 4(2), 73-83.

Ismail, S., Al-Awidi, H., \& Almekhlafi, A. (2012). Employing reading and writing computer-based instruction in English as a second language in elementary schools. International Journal of Business \& Social Science, 3(12), 265-274.

Kea, L. (2011). Using Oral and Written Feedback to Improve Student Writing: An Investigation from Cambodian University Students Perspectives. Royal University of Phnom Penh.

Leki, I.(1990a). Coaching from the Margins: Issues in Written Response. In Barbara Kroll (Ed.), Second Language Writing. Cambridge: Cambridge University Press. (pp 57-68).

Miao, Y. (2006). A comparative study of peer and teacher feedback in a Chinese EFL writing class. Journal of Second Language Writing, Vol 15 (p. 179-200).

N. Maarof, H. Yamat, KL Li (2011). Role of Teacher, Peer and Teacher-Peer Feedback in Enhancing ESL Students' 
Writing. World Applied Sciences Journal, Innovation and Pedagogy for Lifelong Learning:29-35.

Polio, C. (2012). The relevance of second language acquisition theory to the written error correction debate. Journal of Second Language Writing, 21, 375-389.

Truscott, J. (2007). The effect of error correction on learners' ability to write accurately. Journal of Second Language Writing, 16(4), 255-272.

Truscott, J. (1996). The case against grammar correction in L2 writing classes. Language Learning, 46(2), 327-369.

Wang, T., \& Li, L. (2011). Tell me what to do" vs. „guide me through it": Feedback experiences of international doctoral students. Active Learning in Higher Education, 12(2), 101112.

Wei-chen Chuang (2009). The Effects of Four Different Types of Corrective Feedback on EFL Students' Writing in Taiwan, Shih Chien University. (p. 123-138)

Wisker G., et al. 2003. Strategies supporting and enabling the learning conversations of staff and students at postgraduate level. Teach High Ed 8(3):383-397.

Yang, M., Badger, R., \& Yu, Z. (2006). A comparative study of peer and teacher feedback in a Chinese EFL writing class. Journal of Second Language Writing, 15, 179-200.

Zamel, V. (1985). Responding to student writing. TESOL Quarterly, 19 (1), 79-101.

Zhang, S. (1995). Re-examining the affective advantages of peer feedback in the ESL writing class. Journal of Second Language Writing, 4, 209-222. 
